\title{
Pemodelan Pneumonia pada Balita di Surabaya Menggunakan Spatial Autoregressive Models
}

\author{
Ilhamna Aulia, Mutiah Salamah Chamid dan Shofi Andari \\ Jurusan Statistika, Fakultas Matematika dan Ilmu Pengetahuan Alam, Institut Teknologi Sepuluh Nopember (ITS) \\ Jl. Arief Rahman Hakim, Surabaya 60111 Indonesia \\ e-mail: ilhamna123@gmail.com,mutiah_s@statistika.its.ac.id,shofi.andari@statistika.its.ac.id
}

\begin{abstract}
Abstrak-Pneumonia termasuk dalam 10 penyakit terbanyak di Surabaya. Jumlah kasus pneumonia pada balita setiap kecamatan di Surabaya bervariasi dan mengindikasikan adanya hubungan antar wilayah. Hal ini menjadi dasar penggunaan pemodelan spasial untuk mengidentifikasi variabel-variabel yang berpengaruh terhadap pneumonia pada balita. Model spasial autoregressive (spatial autoregressive models, SAR) digunakan untuk mengakomodasi adanya hubungan atau ketergantungan antar sekelumpulan pengamatan atau lokasi. Dalam studi ini, hasil pemodelan SAR untuk kasus pneumonia pada balita pada 31 kecamatan di Surabaya dibandingkan dengan OLS (Ordinary Least Square) menghasilkan model terbaik. Model SAR menghasilkan $R^{2}$ sebesar 42,1\%. Variabel-variabel yang berpengaruh signifikan yaitu kepadatan penduduk $\left(\mathrm{X}_{1}\right)$, persentase rumah tangga bersih dan sehat $\left(X_{4}\right)$, dan persentase balita yang mendapat imunisasi lengkap $\left(X_{5}\right)$.
\end{abstract}

Kata Kunci-Ordinary Least Square, Pneumonia Pada Balita, Surabaya, Spatial Autoregressive Model

\section{PENDAHULUAN}

$\mathrm{P}$ NEUMONIA adalah infeksi pernapasan akut yang menyerang paru-paru pada bagian alveoli, yang merupakan rongga kosong di paru-paru yang berfungsi melakukan pertukaran gas dengan darah. Ketika seseorang menderita pneumonia, maka alveoli akan dipenuhi nanah dan cairan yang membuat kesakitan saat bernapas dan asupan oksigen yang dihirup terbatas [1]. Kejadian pneumonia merupakan salah satu masalah kesehatan yang paling sering muncul di seluruh wilayah Indonesia, tidak terkecuali Kota Surabaya. Pneumonia di Surabaya mengalami penurunan dari tahun 2012 hingga 2014, membuktikan bahwa Surabaya mampu menekan kasus pneumonia dari tahun ke tahun akan tetapi angka pneumonia di Surabaya masih relatif tinggi.

Kota Surabaya memiliki 31 kecamatan, dimana 31 kecamatan tersebut tidak luput dari penyakit pneumonia. Hanya saja jumlah kasus pneumonia di tiap kecamatan Surabaya bervariasi. Sejauh ini, penelitian mengenai faktor-faktor risiko yang mempengaruhi kejadian pneumonia telah banyak dilakukan. Menurut Noviana [2], dengan menggunakan metode regresi logistik biner stratifikasi didapatkan variabel prediktor berpengaruh signifikan terhadap kejadian pneumonia pada masing-masing strata berbeda dan hanya variabel lama pemberian ASI yang signifikan terhadap kejadian pneumonia pada balita di strata daratan sedang dan daratan rendah. Sedangkan menurut Maghfiroh [3], dengan menggunakan geographically weighted poisson regression dan flexibly shaped spatial scan statistic diketahui bahwa variabel persentase balita gizi buruk, balita mendapat vitamin A dua kali, cakupan pelayanan, kepadatan penduduk, PHBS, rumah sehat dan rumah tangga miskin menunjukkan bahwa variabel yang berpengaruh di tiap kecamatan berbeda-beda.

Pneumonia dapat juga dianalisis menggunakan spatial autoregressive models (SAR). Spatial Autoregressive Models merupakan model yang mengikuti proses autoregressive, yaitu ditunjukkan dengan adanya hubungan ketergantungan antar sekumpulan pengamatan atau lokasi. Berbagai penelitian menggunakan metode SAR telah banyak dilakukan penelitian sebelumnya oleh A'yunin [4] tentang pemodelan angka gizi buruk pada balita dan Astuti, Yasin, Sugito [5] tentang pemodelan angka partisipasi murni jenjang pendidikan SMA sederajat. Pada penelitian yang telah dilakukan A'yunin [4] dan Astuti, Yasin, Sugito [5], dapat diketahui bahwa model SAR lebih baik dibandingkan dengan model regresi.

Oleh karena itu, pada penelitian ini digunakan metode SAR. Dimana belum ada penelitian yang mengkaji penyakit pneumonia pada balita dengan memperhatikan aspek spasial pendekatan area. Maka pada penelitian ini akan dilakukan pemodelan pada jumlah kasus penyakit pneumonia pada balita di Surabaya dengan menggunakan metode SAR dan unit penelitiannya yaitu 31 kecamatan di Kota Surabaya. Variabel yang akan digunakan yaitu terkait faktor-faktor lingkungan, kesehatan dan perilaku rumah tangga. Dengan adanya penelitian ini diharapkan mampu menghasilkan model kasus pneumonia pada balita yang spesifik di setiap wilayah sehingga hasilnya diharapkan mampu memberi informasi bagi pemerintah dalam menekan jumlah kasus pneumonia di Surabaya dan mengetahui faktor-faktor apa saja yang mempengaruhi kasus pneumonia pada balita di Surabaya.

\section{TINJAUAN PUSTAKA}

\section{A. Regresi Linier}

Regresi linear berganda merupakan metode yang memodelkan hubungan antara variabel respon $(Y)$ dan variabel prediktor $\left(X_{1}, X_{2}, X_{3}, \ldots, X_{p}\right)$. Secara umum model regresi linier dapat ditulis sebagai berikut [6].

$$
Y_{i}=\beta_{0}+\sum_{k=1}^{p} \beta_{k} X_{i k}+\varepsilon_{i}
$$

$Y$ adalah variabel dependen, $\beta_{k}=$ koefisien regresi, $X_{k}$ adalah variabel independen atau variabel bebas, $\varepsilon_{i}$ adalah nilai error regresi dengan $\varepsilon \sim \operatorname{IIDN}(0, \sigma)$

Salah satu cara untuk menduga koefisien regresi dengan estimator OLS (Ordinary Least Square) untuk $\beta$ sebagai berikut [6].

$$
\widehat{\boldsymbol{\beta}}=\left(\boldsymbol{X}^{T} \boldsymbol{X}\right)^{-1} \boldsymbol{X}^{T} \boldsymbol{y}
$$


$\widehat{\boldsymbol{\beta}}$ adalah vektor dari parameter yang diestimasi berukuran $(p+1) x 1, \boldsymbol{X}$ adalah matriks variabel prediktor berukuran $n x$ $(p+1), \mathbf{y}$ adalah vektor observasi dari variabel respon berukuran $n \times 1$. Setelah mendapatkan model (1), dilakukan uji signifkansi parameter secara serentak dan parsial.

\section{B. Aspek Spasial}

Aspek spasial yang terjadi antar wilayah dapat dibagi menjadi dua jenis, yaitu dependensi spasial dan heterogenitas spasial. Uji dependensi spasial dilakukan dengan uji Moran's I dan Lagrange Multiplier (LM). Statistik uji untuk uji Moran's I adalah sebagai berikut [7].

$$
\begin{gathered}
I=\frac{n \sum_{i=1}^{n} \sum_{j=1}^{n} \boldsymbol{w}_{i j}\left(Y_{i}-\bar{Y}\right)\left(Y_{j}-\bar{Y}\right)}{S_{0} \sum_{i=1}^{n}\left(Y_{i}-\bar{Y}\right)^{2}} \\
E(I)=I_{0}=-\frac{1}{n-1}
\end{gathered}
$$

Identifikasi pola menggunakan kriteria nilai indeks $I$, yaitu jika $I>I_{0}$ maka memiliki pola mengelompok (cluster), $I<I_{0}$ memiliki pola menyebar. Jika $I=I_{0}$ maka memiliki pola menyebar tidak merata (tidak ada autokorelasi), dan $I \neq I_{0}$ berarti terjadi autokorelasi positif saat $I$ positif dan sebaliknya terjadi autokorelasi negatif saat $I$ negatif.

Uji Lagrange Multiplier (LM) adalah uji untuk menentukan apakah model memiliki efek spasial atau tidak. LM yaitu residual dari OLS yang diberi efek spasial dalam bentuk matrik bobot spasial (W). Hipotesis yang digunakan sebagai berikut.

$\mathrm{H}_{0}: \rho=0$ (tidak ada dependensi spasial)

$\mathrm{H}_{1}: \rho \neq 0$ (ada dependensi spasial)

Statistik uji untuk LM sebagai berikut.

$$
L M_{\text {lag }}=\frac{\left(\frac{\boldsymbol{e}^{\prime} \boldsymbol{W} \boldsymbol{y}}{\sigma^{2}}\right)^{2}}{\frac{(\boldsymbol{W} \boldsymbol{X} \boldsymbol{\beta})^{\prime} \boldsymbol{M} \boldsymbol{W} \boldsymbol{X} \boldsymbol{\beta}}{\sigma^{2}}+\operatorname{tr}\left[\left(\boldsymbol{W}^{\prime}+\boldsymbol{W}\right) \boldsymbol{W}\right]}
$$

Pengambilan keputusan adalah tolak $\mathrm{Ho}$ jika $L M>\chi_{(\alpha, 1)}^{2}$ atau p-value $<\alpha(0,05)$ yang berarti terjadi dependensi spasial lag pada variabel dependen.

Pengujian adanya heterogenitas spasial dapat dilakukan dengan menggunakan uji Breusch-Pagan (BP) dimana hipotesis yang digunakan sebagai berikut.

$\mathrm{H}_{0}: \sigma_{1}^{2}=\sigma_{2}^{2}=\cdots=\sigma^{2}$ (karakteristik di suatu lokasi homogen) $\mathrm{H}_{1}: \sigma_{i}^{2} \neq \sigma^{2}, \mathrm{i}=1,2, \ldots, \mathrm{n}$ (karakteristik di suatu lokasi heterogen) Statistik uji untuk Breusch-Pagan adalah sebagai berikut.

$$
B P=\left(\frac{1}{2}\right) \boldsymbol{f}^{T} \boldsymbol{Z}\left(\boldsymbol{Z}^{T} \boldsymbol{Z}\right)^{-1} \boldsymbol{Z}^{T} \boldsymbol{f}
$$

Daerah penolakan :

Tolak Ho jika BP $>X_{\propto ; p}^{2}$ atau jika P-value $<\alpha$ dengan $\mathrm{p}$ adalah banyaknya prediktor.

\section{Spatial Autoregressive Model}

Spatial Autoregressive Model (SAR) adalah salah satu model spasial pendekatan area dengan memperhitungkan pengaruh spasial lag pada variabel dependen saja. Model SAR merupakan pengembangan model autoregressive order pertama [7].

$$
\boldsymbol{Y}_{\boldsymbol{i}}=\boldsymbol{\beta}_{\mathbf{0}}+\rho \sum_{j=1, i \neq j}^{n} \boldsymbol{w}_{i j} \boldsymbol{Y}_{j}+\boldsymbol{X}_{\boldsymbol{i}} \boldsymbol{\beta}+\boldsymbol{\varepsilon}_{\boldsymbol{i}}
$$

\section{Estimasi Parameter}

Estimasi parameter dilakukan dengan menggunakan Maximum Likelihood Estimation (MLE). Estimasi paramater $\beta$ diperoleh dengan memaksimumkan fungsi ln likelihood dengan mendifferensialkan persamaan tersebut terhadap $\beta$ sehingga didapatkan estimasi paramater sebagai berikut.

$$
\widehat{\boldsymbol{\beta}}=\left(X^{T} X\right)^{-1} X^{T}\left(I-\rho W_{1}\right) y
$$
adalah:

Sedangkan fungsi logaritma natural untuk mengestimasi $\rho$

$$
\begin{gathered}
f(\rho)=c-\frac{n}{2} \ln \left\{\left[\boldsymbol{e}_{\boldsymbol{o}}-\rho \boldsymbol{e}_{\boldsymbol{d}}\right]^{T}\left[\boldsymbol{e}_{\mathbf{0}}-\rho \boldsymbol{e}_{\boldsymbol{d}}\right]\right\}+ \\
\left(+\ln \left|\boldsymbol{I}-\rho \boldsymbol{W}_{\mathbf{1}}\right|\right) \\
\text { dengan } c=-\frac{n}{2} \ln (2 \pi)-\frac{n}{2} \ln (n)-\frac{1}{2} \\
\boldsymbol{e}_{\mathbf{0}}=\boldsymbol{Y}-\boldsymbol{X} \boldsymbol{\beta}_{\mathbf{0}} \operatorname{dan} \boldsymbol{e}_{\boldsymbol{d}}=\boldsymbol{W}_{\mathbf{1}} \boldsymbol{Y}-\boldsymbol{X} \boldsymbol{\beta}_{\boldsymbol{d}}
\end{gathered}
$$

\section{E. Pembobot Spasial}

Pembobot spasial yang digunakan dalam penelitian ini adalah queen contiguity (persinggungan sisi-sudut) dengan order of contiguity sebesar empat. Metode queen contiguity mendefinisikan bahwa lokasi yang bersisian atau titik sudutnya bertemu dengan lokasi yang menjadi perhatian diberi pembobotan $w_{i j}=1$, sedangkan untuk lokasi lainnya adalah $w_{i j}$ $=0[4]$.

\section{F. Pneumonia}

Pneumonia adalah penyakit yang terjadi karena adanya infeksi akut pada jaringan paru-paru. Sebagian besar Pneumonia disebabkan oleh bakteri, virus maupun jamur. Virus, bakteri, dan jamur penyebab pneumonia antara lain adalah streptococcus pneumoniae, haemophilus influenzae, respiratory syncytial virus (RSV), pneumocystis jiroveci $(\mathrm{FCP})$.

Penyakit pneumonia dapat disebabkan oleh beberapa faktor risiko yang saling mempengaruhi yaitu kepadatan penduduk, status gizi balita, ASI eksklusif, rumah tangga berperilaku bersih dan sehat (PHBS), dan status imunisasi campak [8].

\section{METODOLOGI PENELITIAN}

\section{A. Sumber Data}

Data yang digunakan dalam penelitian ini adalah data sekunder yang diperoleh dari Dinas Kesehatan Surabaya mengenai kasus pneumonia di Kota Surabaya. Data sekunder yang digunakan merupakan data pada tahun 2014 dengan unit observasi sebanyak 31 kecamatan di Surabaya.

\section{B. Variabel Penelitian}

Variabel yang digunakan dalam penelitian ini adalah sebagai berikut:

1. Variabel respon $(Y)$ adalah persentase kasus penyakit pneumonia pada balita di Surabaya.

2. Variabel prediktor $(X)$, terdiri dari variabel-variabel yang diduga berpengaruh terhadap variabel respon. Berikut merupakan variabel prediktor yang digunakan.
a. Kepadatan penduduk di Surabaya $\left(X_{1}\right)$
b. Balita gizi buruk di Surabaya $\left(X_{2}\right)$
c. Balita mendapatkan ASI eksklusif di Surabaya $\left(X_{3}\right)$
d. Rumah tangga berperilaku bersih dan sehat di Surabaya $\left(X_{4}\right)$
e. Balita mendapatkan imunisasi lengkap di Surabaya $\left(X_{5}\right)$




\section{Langkah-Langkah Analisis Data}

Langkah awal yang dilakukan sebelum menganalisis dengan metode yang digunakan adalah sebagai berikut :

1. Mendeskripsikan kasus penyakit pneumonia di Kota Surabaya tahun 2014 serta faktor-faktor risiko yang diduga mempengaruhinya menggunakan rata-rata, varians, minimum dan maksimum.

2. Menganalisis model kasus penyakit pneumonia di Kota Surabaya menggunakan regresi linier berganda dengan langkah-langkah sebagai berikut.

a. Melakukan estimasi parameter model regresi linier berganda.

b. Melakukan pengujian signifikansi parameter.

3. Melakukan pengujian aspek spasial, uji dependensi serta heterogenitas spasial pada kasus penyakit pneumonia di Surabaya.

4. Melakukan pemodelan dengan metode spatial autoregressive model dengan langkah-langkah sebagai berikut.

a. Menentukan pembobot spasial

b. Estimasi parameter spatial autoregressive model.

5. Menginterpretasikan dan menyimpulkan hasil yang diperoleh.

\section{ANALISIS DAN PEMBAHASAN}

\section{A. Karakteristik Persentase Pneumonia Pada Balita dan} Faktor-faktor yang Mempengaruhi

Kota Surabaya memiliki kasus pneumonia yang cukup tinggi. Kota Surabaya pun terdiri dari 31 kecamatan dimana di tiap kecamatan memiliki variasi kasus pneumonia yang berbeda-beda. Kasus pneumonia di Surabaya pada tahun 2014 sebanyak 4306 kasus. Kecamatan yang memiliki kasus pneumonia terbanyak yaitu Kecamatan Wonocolo dengan jumlah kasus pneumonia sebanyak 484 kasus. Sedangkan pada Kecamatan Bulak dan Kecamatan Dukuh Pakis tidak terjadi kasus pneumonia.

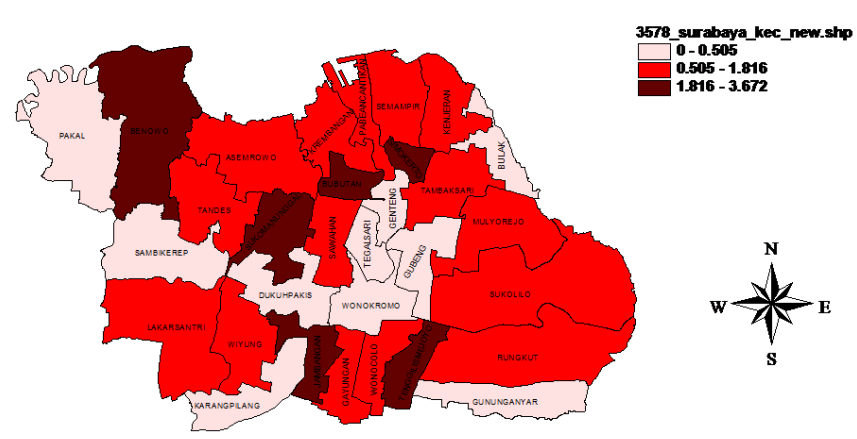

Gambar 1. Persebaran Persentase Kasus Pneumonia di Surabaya Tahun 2014 Berdasarkan Kecamatan

Gambar 1. di atas menunjukkan persebaran persentase kasus pneumonia yang terjadi di setiap kecamatan Surabaya terbagi menjadi tiga kategori berdasarkan tiga interval yang sama yaitu kategori rendah, kategori sedang, dan kategori tinggi. Kecamatan yang persentase kasus pneumonia tertinggi dapat dilihat pada Gambar 1. bewarna merah pekat dengan interval $1.816 \%-3.672 \%$ ada enam kecamatan yaitu Kecamatan Benowo, Kecamatan Simokerto, Kecamatan Sukomanunggal,
Kecamatan Bubutan, Kecamatan Jambangan, dan Kecamatan Tenggilis Mejoyo. Sedangkan kecamatan yang persentase kasus pneumonia dalam kategori sedang dengan interval $0.505 \%$ $1.816 \%$ terdapat 15 kecamatan. Pada Gambar 1. terdapat pula kecamatan dimana persentase kasus pneumonia rendah dengan interval 0\%-0.505\% sebanyak 10 kecamatan.

Tabel 1.

Statistika Deskriptif dan Pengujian Dependensi Spasial

\begin{tabular}{crrrr}
\hline \hline Variabel & \multicolumn{1}{c}{ Rata-rata } & Maksimum & \multicolumn{1}{c}{ Minimum } & \multicolumn{1}{c}{ Moran's I } \\
\hline$Y$ & 1,41 & 8,03 & 0,00 & 0.07800 \\
$X_{1}$ & 11405,00 & 31361,00 & 2201,00 & -0.42700 \\
$X_{2}$ & 0,18 & 0,91 & 0,02 & 0.22000 \\
$X_{3}$ & 65,63 & 88,35 & 44,80 & -0.06500 \\
$X_{4}$ & 68,74 & 95,88 & 42,66 & 0.00019 \\
$X_{5}$ & 97,85 & 148,70 & 75,25 & -0.17000 \\
\hline \hline
\end{tabular}

Tabel 1. menunjukkan nilai rata-rata, standart deviasi, minimum dan maksimum setiap variabel yang digunakan dalam penelitian. Rata-rata persentase kasus pneumonia pada kecamatan di Surabaya $(Y)$ adalah $1,211 \%$. Terdapat 15 kecamatan di Surabaya yang memiliki angka persentase kasus pneumonia lebih tinggi dari rata-rata dan 16 kecamatan memiliki angka persentase kasus pneumonia lebih rendah dari rata-rata. Sedangkan untuk nilai maksimum sebesar 3,672\% kasus pneumonia di Kecamatan Tenggilis Mejoyo dan tidak terdapat kasus pneumonia pada balita di Kecamatan Bulak dan Kecamatan Dukuh Pakis.

\section{B. Analisis Regresi Linier Berganda}

Model regresi OLS dapat ditulis sebagai berikut.

$$
\hat{Y}=2,72+0,0325 X_{4}-0,0383 X_{5}
$$

Hasil uji signifikansi parameter didapatkan variabel yang siginifikan adalah variabel rumah tangga berperilaku bersih dan sehat $\left(X_{4}\right)$ dan balita mendapat imunisasi lengkap $\left(X_{5}\right)$. Model ini menghasilkan $\mathrm{R}^{2}$ sebesar $26,4 \%$. Nilai ini berarti model yang terbentuk dapat menjelaskan keragaman kasus pneumonia pada balita sebesar 73,6\%, sedangkan sisanya dijelaskan oleh variabel lain yang tidak masuk ke dalam model. Nilai $\mathrm{R}^{2}$ yang kecil pada penelitian ini disebabkan terdapat nilai pengamatan yang jauh berbeda dibandingkan dengan nilai pengamatan lainnya. Tetapi penelitian tetap dilanjutkan sebagaimana adanya data karena untuk menghindari hilangnya informasi di suatu kecamatan.

\section{Pengujian Aspek Spasial}

Pengujian aspek data spasial meliputi dua hal, yaitu uji dependensi spasial dan uji heterogenitas spasial.

1. Uji Dependensi Spasial

Pengujian dependensi spasial merupakan pengujian yang dilakukan untuk melihat apakah pengamatan di suatu lokasi berpengaruh terhadap pengamatan di lokasi lain yang letaknya saling berdekatan. Pengujian dependensi spasial dilakukan dengan uji Moran's I dan Langrange Multiplier. Moran's I dilakukan untuk mengetahui dependensi spasial atau autokorelasi pada masing-masing variabel sedangkan Lagrange Multiplier digunakan untuk mengetahui dependensi pada lag atau error. Berikut merupakan hipotesis uji dependensi spasial.

Berdasarkan Tabel 1., terdapat tiga variabel yang memiliki nilai Moran's $I$ lebih besar dari $\mathrm{I}_{0}=-0,0333$ yang menunjukkan bahwa terdapat autokorelasi positif atau pola yang mengelompok dan memiliki kesamaan karakteristik pada lokasi 
yang berdekatan. Sedangkan untuk variabel kepadatan penduduk $\left(X_{1}\right)$, variabel balita mendapat ASI eksklusif $\left(X_{3}\right)$, dan variabel balita mendapat imunisasi lengkap $\left(X_{5}\right)$ memiliki nilai Moran's $I$ lebih kecil dari $\mathrm{I}_{0}=-0,0333$. Hal ini menunjukkan bahwa data berpola menyebar.

Pengujian Lagrange Multiplier yang menghasilkan nilai probabilitas yang lebih kecil dengan taraf signifikansi $(\alpha=0,10)$ yaitu 0,06 . Sehingga $\mathrm{H}_{0}$ ditolak artinya terdapat dependensi spasial lag sehingga perlu dilanjutkan ke pembuatan model dengan menggunakan Spatial Autoregressive Models (SAR).

2. Uji Heterogenitas Spasial

Pengujian heterogenitas spasial dilakukan untuk mengetahui adanya keberagaman dalam hubungan secara kewilayahan. Heterogenitas spasial dapat diidentifikasi dengan menggunakan pengujian Breusch Pagan. P-value statistik uji Breusch-Pagan sebesar 0,33 lebih dari $\alpha=0,10$ yang artinya tidak terdapat heterogenitas spasial pada data yang diamati.

\section{Spatial Autoregressive Model}

Berdasarkan hasil uji Lagrange Multiplier pada lag, pada kasus ini perlu dilakukan penaksiran parameter untuk SAR dimana hasil penaksiran parameternya adalah sebagai berikut.

Tabel 2.

Estimasi Parameter SAR

\begin{tabular}{crr}
\hline \hline Estimasi & Koefisien & P-value \\
\hline$\rho$ & 0,516000 & 0,013 \\
$\beta_{0}$ & 1,791000 & 0,145 \\
$\beta_{1}$ & 0,000038 & 0,054 \\
$\beta_{2}$ & $-0,041000$ & 0,953 \\
$\beta_{3}$ & $-0,009000$ & 0,432 \\
$\beta_{4}$ & 0,036000 & 0,003 \\
$\beta_{5}$ & $-0,035000$ & 0,002 \\
\hline \hline
\end{tabular}

Pada variabel kepadatan penduduk $\left(X_{l}\right)$ mempunyai nilai koefisien bernilai positif. Hal ini menunjukkan bahwa kecamatan yang berdekatan dengan kecamatan lain yang memiliki jumlah kepadatan penduduk tinggi maka kasus pneumonia pada balita cenderung tinggi. Pada variabel rumah tangga berperilaku sehat dan bersih (PHBS) $\left(X_{4}\right)$ juga memiliki nilai koefisien bernilai positif, menunjukkan kecamatan yang berdekatan dengan kecamatan lain dan memiliki nilai persentase PHBS tinggi maka kasus pneumonia pada balita cenderung tinggi.

Sedangkan pada variabel balita gizi buruk $\left(X_{2}\right)$, balita mendapat ASI eksklusif $\left(X_{3}\right)$, dan balita mendapat imunisasi lengkap $\left(X_{5}\right)$ memiliki nilai koefisien bernilai negatif. Hal ini menunjukkan bahwa kecamatan yang berdekatan dengan kecamatan lain yang memiliki persentase tinggi maka akan kasus pneumonia pada balita cenderung rendah.

Tabel 2. terdapat tiga variabel yang berpengaruh signifikan terhadap $\alpha=0,10$ adalah variabel kepadatan penduduk $\left(\mathrm{X}_{1}\right)$, variabel rumah tangga berperilaku bersih dan sehat $\left(\mathrm{X}_{4}\right)$, dan variabel balita mendapatkan imunisasi lengkap $\left(\mathrm{X}_{5}\right)$. Secara umum model SAR menggunakan taraf signifikansi $10 \%$ adalah sebagai berikut.

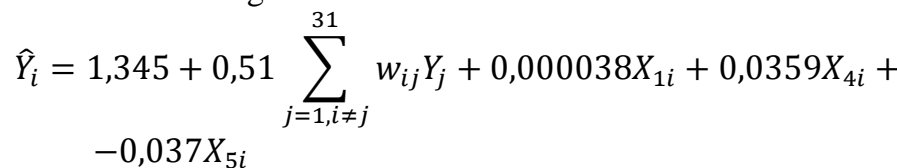

\section{E. Pemilihan Model Terbaik}

Setelah melakukan estimasi parameter pada masing-masing model. Mencari model terbaik yaitu dengan melihat nilai $\mathrm{R}^{2}$ paling besar dan nilai AIC paling kecil, dimana nilai $\mathrm{R}^{2}$ dan nilai AIC pada masing-masing model adalah sebagai berikut.

Tabel 3.

$\mathrm{R}^{2}$ Masing-Masing Model

\begin{tabular}{ccc}
\hline \hline Model & $\mathrm{R}^{2}$ & $\mathrm{AIC}$ \\
\hline $\begin{array}{l}\text { Ordinary Least Square } \\
\text { Spatial Autoregressive Model }\end{array}$ & $26,4 \%$ & 82,156 \\
$\hat{Y}_{i}=1,345+0,51 \sum_{j=1, i \neq j}^{31} w_{i j} y_{j}+0,000038 X_{1 i}+0,0359 X_{4 i}$
\end{tabular}
sebesar 43,4\%. Hal ini menunjukkan bahwa variasi pneumonia pada balita sebesar $42,1 \%$ dan sisanya $57,9 \%$ dijelaskan oleh variabel lain di luar model. Dengan nilai $\mathrm{R}^{2}$ pada model SAR sebesar $42,1 \%$, model SAR dapat dikatakan cukup baik untuk menjelaskan variasi dari persentase kasus pneumonia pada balita di Surabaya.

Secara umum, model SAR dapat diinterpretasikan bahwa apabila faktor lain dianggap konstan maka ketika kepadatan penduduk $\left(X_{1}\right)$ naik sebesar 1 jiwa/ $\mathrm{km}^{2}$ maka persentase kasus pneumonia pada balita di Surabaya akan bertambah sebanyak 1 balita dalam satu tahun. Kemudian apabila rumah tangga berperilaku bersih dan sehat $\left(X_{4}\right)$ bertambah satu persen maka persentase pneumonia pada balita akan naik sebanyak 1 balita dalam satu tahun. Dan apabila balita mendapat imunisasi lengkap $\left(X_{5}\right)$ bertambah satu persen maka persentase pneumonia pada balita akan turun sebanyak 1 balita dalam satu tahun.

\section{KESIMPULAN DAN SARAN}

\section{A. Kesimpulan}

Kesimpulan yang diperoleh dari hasil analisis dan pembahasan pada penelitian ini adalah sebagai berikut.

Setelah melakukan pemodelan dengan menggunakan Ordinary Least Square dan Spatial Autoregressive Model maka didapatkan model yang memiliki nilai $\mathrm{R}^{2}$ tertinggi yaitu Spatial Autoregressive Model dengan nilai $\mathrm{R}^{2}$ sebesar $42,1 \%$. Model Spatial Autoregressive yang dihasilkan adalah sebagai berikut.

$$
\begin{aligned}
\hat{Y}_{i}= & 1,345+0,51 \sum_{j=1, i \neq j}^{31} w_{i j} Y_{j}+0,000038 X_{1 i}+0,0359 X_{4 i}+ \\
& -0,037 X_{5 i} \\
& \text { Dengan } \hat{Y}_{i} \text { sebagai variabel respon untuk prediksi }
\end{aligned}
$$
persentase pneumonia pada balita pada kecamatan ke $i$. Pada pemodelan Spatial Autoregressive, didapatkan bahwa dari lima variabel prediktor hanya tiga variabel yang signifikan pada $\alpha=$ $10 \%$ yaitu variabel kepadatan penduduk $\left(X_{1}\right)$, persentase rumah tangga bersih dan sehat $\left(X_{4}\right)$, dan persentase balita mendapat imunisasi lengkap $\left(X_{5}\right)$.

\section{B. Saran}

Pada penelitian ini, kasus pneumonia pada balita di Surabaya sudah cocok menggunakan spatial autoregressive models hanya saja, kecamatan ke $i$ masih terlalu jauh bersinggungan dengan kecamatan ke $j$. Maka untuk penelitian selanjutnya, kasus pneumonia pada balita di Surabaya 
disarankan menggunakan pemodelan non linier yang lebih cocok.

\section{DAFTAR PUSTAKA}

[1] World Health Organization. 2016. Pneumonia. Diakses pada 13 Februari 2016, dari http://www.who.int/media centre/factsheets/fs331/en/.

[2] Noviana, Ita. 2013. Pemodelan Resiko Penyakit Pneumonia pada Balita di Jawa Timur Menggunakan Regresi Logistik Biner Stratifikasi. Surabaya: Penelitian Jurusan Statistika FMIPA ITS.

[3] Maghfiroh, F. N. 2015. Pemodelan Kasus Pneumonia Balita di Kota Surabaya dengan Geographically Weighted Poisson Regression dan Flexibly Shaped. Surabaya: Penelitian Jurusan Statistika FMIPA ITS.

[4] A'yunin, Q. 2011. Pemodelan Angka Gizi Buruk Pada Balita Di Kota Surabaya Dengan Spatial Autoregressive Model (SAR). Surabaya: Penelitian Jurusan Statistika FMIPA ITS.

[5] Astuti, R.D.K., Yasin. H., \& Sugito. 2013. Aplikasi Model Spatial Autoregressive Untuk Pemodelan Angka Partisipasi Murni Jenjang Pendidikan SMA Sederajat Di Provinsi Jawa Tengah Tahun 2011. Semarang: Universitas Diponegoro.

[6] Draper, N.R., \& Smith, H. 1992. Analisis Regresi Terapan Edisi Kedua. Jakarta: PT. Gramedia Pustaka Utama.

[7] Anselin L. 1988. Spatial Econometrics: Methods and Models. Dordrecht: Kluwer Academic Publishers.

[8] Direktorat Jenderal Pengendalian Penyakit \& Penyehatan Lingkungan. 2012. Pemodelan Pengendalian Infeksi Saluran Pernafasan Akut. Jakarta: Kementerian Kesehatan RI. 